\title{
Barrett's esophagus associates with a variant of IL23R gene
}

\author{
Pawel Gaj, Michal Mikula, Lucjan S. Wyrwicz, Jaroslaw Regula and Jerzy Ostrowski ${ }^{\bowtie}$ \\ Department of Gastroenterology and Hepatology, Medical Center for Postgraduate Education at the Maria \\ Skłodowska-Curie Memorial Cancer Center and Institute of Oncology, Warszawa, Poland
}

Received: 25 April, 2008; revised: 20 May, 2008; accepted: 02 June, 2008

available on-line: 14 June, 2008

\begin{abstract}
Gastroesophageal reflux disease is regarded as a spectrum of diseases: non-erosive reflux disease (NERD), erosive reflux disease (ERD), and the far end of the spectrum represented by patients with Barrett's esophagus. Among predisposing factors, both risk and protective polymorphic variants of several genes may influence the clinical outcomes of reflux disease. Consequently, different molecular mechanisms are likely to underlie the development of clinical variants of reflux disease. Ninety six patients with reflux disease were screened for polymorphisms of CARD15, SLC22A4 (OCTN1), SLC22A5 (OCTN2), DLG5, ATG16L1 and IL23R genes which had previously been found to associate with immune-mediated chronic inflammatory disorders. While none of the polymorphisms were associated with NERD or ERD, the 1142G/A variant of the IL23R gene was found to be a risk variant in Barrett's esophagus patients. The IL23/IL23R pathway may modulate STAT3 transcriptional activity which is an essential regulator not only of immune-mediated inflammation, but also of inflammatory-associated apoptosis resistance. Although the mechanisms of metaplastic transition of inflamed squamous epithelium are undetermined as yet, our findings suggest potential involvement of alternations in the IL23/IL23R pathway as a molecular background of Barrett's esophagus development.
\end{abstract}

Keywords: Barrett's esophagus, risk, SNP, IL23R, association study

\section{INTRODUCTION}

Barrett's esophagus is a complex multifactorial disease that results from molecular and cellular adaptation processes to environmental factors modulated by as yet undetermined genetic determinants. Environmental factors involved in the development of Barrett's esophagus are relatively well-defined and related mainly to stress conditions induced by gastroesophageal reflux components, such as hydrochloric acid, peptidases, lipases, and bile acids. Chronic exposure of esophageal mucosa to these noxious factors can lead to inflammation of $\mathrm{mu}-$ cosa coated with squamous epithelium which progresses from mild forms (non-erosive reflux disease - NERD), through intermediate forms (erosive reflux disease - ERD) to advanced forms of Barrett's esophagus. Barrett's esophagus is characterized by the replacement of squamous epithelium with specialized intestinal metaplastic mucosa. The clinical relevance of Barrett's metaplasia comes from the fact that it represents a well-defined precursor lesion of esophageal adenocarcinoma.

The metaplastic transition of inflamed squamous epithelium depends on the induction of undefined pathways of organogenesis in the adult esophagus (Krishnadath, 2007). However, the fundamental question regarding gastroesophageal reflux disease patients is why only a subset of patients undergoes progression to Barrett's esophagus. We have recently shown that tissue samples from normal, non-metaplastic and non-erosive squamous epithelium from NERD, ERD and Barrett's esophagus patients exhibit two different patterns of gene expression (Ostrowski et al., 2006). Consequently, NERD and Barrett's esophagus, with molecularly divisible

${ }^{\square}$ Corresponding author: Jerzy Ostrowski, Department of Gastroenterology and Hepatology, Medical Center for Postgraduate Education in Cancer Center, W. Roentgena 5, 02-781 Warszawa, Poland; phone: (48) 22 644 0102; fax: (48) 22 644 0209; e-mail: jostrow@warman.com.pl.

Abbreviations: ERD, erosive reflux disease; NERD, non-erosive reflux disease. 
conditions, may be regarded as two different variants of gastroesophageal reflux disease, while ERD remains heterogeneous, characterized by a transcriptional pattern similar to either NERD or Barrett's esophagus. Our findings indicated that progression in squamous epithelium inflammation may depend on coordinated changes in mucosal gene expression. Moreover, we speculated that these changes are determined by genetic predisposition that contributes to disease susceptibility.

Studies of gastroesophageal reflux disease have indicated a gender bias with NERD and Barrett's esophagus; while NERD is the dominant form of gastroesophageal reflux disease in female patients, Barrett's esophagus is observed more often in males. Similar sexual bias was also observed in disorders related to aberrant autoimmune response, and therefore genes related to the regulation and execution of inflammatory processes are candidates for screening in genotype-phenotype association studies.

Inflammation is mediated and modulated by interleukins (ILs) modulated by interleukins (ILs) (Koj \& Jura, 2003). Several studies of Barrett's esophagus genetic predisposition have identified both risk and protective polymorphic variants of several genes involved in disease susceptibility. These include functional polymorphisms of the IL1R and IL10 genes and variants of genes encoding enzymes, such as GSTP1 and NQO1 (Gough et al., 2005; di Martino et al., 2007; Kala et al., 2007). Several of these findings have not been confirmed by other studies (Murphy et al., 2007).

This study shows for the first time that a variant of IL23R is associated with Barrett's esophagus patients.

\section{MATERIALS AND METHODS}

The study included 96 patients with gastroesophageal reflux disease and 139 healthy volunteers (74 men, range of 21-66 years old, median 32) recruited from hospital staff, medical students, and healthy subjects selected for screening colonoscopy. Patient characteristics are presented in Table 1. All patients and controls were Polish Caucasians. The study was approved by the local ethics committee, and all the participants provided appropriate consent.
Genomic DNA was extracted from whole blood treated with EDTA using the NucleoSpin Blood Quick Pure kit (Macherey-Nagel, Germany), following the manufacturer's protocol. The selected polymorphisms of genes were as follows: CARD15 - rs2066842 (Pro268Ser), rs2066844 (Arg702Trp), rs2066845 (Gly908Arg), rs5743293 (1007fs); SLC22A4(OCTN1), - rs1050152 (Leu503Phe), SLC22A5 (OCTN2) - rs2631367 (-207G>C); DLG5 - rs1248696 (Arg30Gln); ATG16L1 rs2241880 (Thr300Ala); IL23R - rs11209026 (Arg381Gln), rs1884444 (His3Gln), rs10889677 (exon-3' UTR).

Genotyping was carried out using TaqMan SNP Genotyping Assays (Applied Biosystems, Foster City, CA, USA). The PCR reactions were performed in 96-well plates on the ABI PRISM 7000 Sequence Detection System (SDS) (Applied Biosystems), and fluorescence was acquired and analyzed for allelic discrimination using the ABI Prism 7000 SDS Software.

The frequency distribution of alleles, genotypes, and haplotypes was compared using standard or Yates corrected $\chi^{2}$ test and Fisher's exact test when appropriate. Statistical significance threshold level was Bonferroni corrected for multiple hypothesis testing, according to the number of genes tested. The $p$-value significance threshold level was defined as 0.008. For the Fisher's exact tests, the STATISTICA software was used. ORs with $95 \%$ confidence intervals (95\% CI) were calculated using a calculator available at http://www.hutchon.net/ConfidOR.htm. LD analysis and calculation of the Hardy-Weinberg equilibrium were performed using the Haploview v.3.2 software, available at http://www.broad.mit. edu/mpg/haploview/.

\section{RESULTS}

In the studied groups, genotype distributions for all polymorphisms were in Hardy-Weinberg equilibrium $(p>0.05)$. None of the polymorphisms were significantly associated with the reflux disease patients (not shown) except for one variant of the interleukine-23 receptor (IL23R) gene. This coding variant (1142G/A; Arg381Gln; rs11209026) showed a weak association with gastroesophageal reflux disease patients $(\mathrm{OR}=3.49$; $95 \% \mathrm{CI}=1.37-8.90$; $p=0.011)$, although the $p$-value did not pass the Bon-

Table 1. Characteristics of studied 96 patients

\begin{tabular}{llll}
\hline & Non-erosive reflux disease & Erosive reflux disease & Barrett's esophagus \\
\hline No. of patients (males) & $30(3)$ & $32(16)$ & $34(30)$ \\
Age, median (range) & $50(19-74)$ & $55(26-73)$ & $57(29-78)$ \\
Body mass index, median & 26.5 & 28.6 & 26.1 \\
$($ Ex-) Smokers, n (\%) & $14(47)$ & $19(59)$ & $20(59)$ \\
\hline
\end{tabular}


Table 2. Allelic distribution for the coding variants of IL23R (1142G/A; Arg381Gln; rs11209026) in reflux disease patients and control group

\begin{tabular}{|c|c|c|c|}
\hline \multirow{2}{*}{ Group } & \multicolumn{2}{|c|}{ IL23R (Arg381Gln; rs11209026) } & \multirow{2}{*}{ p-value } \\
\hline & $\mathrm{G} / \mathrm{G}$ & $\mathrm{G} / \mathrm{A}+\mathrm{A} / \mathrm{A}$ & \\
\hline Healthy controls $(\mathrm{N}=139)$ & $132(95.0 \%)$ & $7(5.0 \%)$ & - \\
\hline Gastroesophageal reflux disease $(\mathrm{N}=96)$ & $81(84.4 \%)$ & $15(15.6 \%)$ & 0.011 \\
\hline Non-erosive reflux disease $(\mathrm{N}=30)$ & $26(86.7 \%)$ & $4(13.3 \%)$ & 0.11 \\
\hline Erosive reflux disease $(\mathrm{N}=32)$ & $30(93.8 \%)$ & $2(6.3 \%)$ & 0.68 \\
\hline Barrett's esophagus $(\mathrm{N}=34)$ & $25(73.5 \%)$ & $9(26.5 \%)$ & 0.0007 \\
\hline
\end{tabular}

*The frequency allele distribution was compared using standard or Yates corrected $\chi^{2}$ test and Fisher's exact test when appropriate. Statistical significance threshold level was Bonferroni corrected for multiple hypothesis testing, according to the number of genes tested. The $P$-value significance threshold level was defined as 0.008 .

ferroni corrected significance threshold level of 0.008 (Table 2). However, when the polymorphism was examined separately in NERD, ERD and Barrett's esophagus subgroups and compared to the group of healthy controls, a significant association was found with Barrett's esophagus (OR $=6.79 ; 95 \% \mathrm{CI}$ $=2.31-19.90 ; p=0.0007)$ but not with NERD or ERD (Table 2). None of the subjects was homozygous for the AA genotype. The frequencies of the two more frequent variants of IL23R, rs1884444 (His3Gln) and rs10889677 (exon-3' UTR), were similar among the studied patient groups and the group of healthy controls.

\section{DISCUSSION}

The IL23R gene is located on chromosome region 1p31, and encodes a subunit of the IL23 receptor. Several genetic non-coding variants of IL23R demonstrated independent risk association with chronic inflammatory disorders, such as inflammatory bowel disease (Duerr et al., 2006), psoriasis, T-cellmediated inflammatory disease of the skin (Cargill et al., 2007), and ankylosing spondylitis (Burton et al., 2007), and the investigated variant (Arg381Gln, A allele of rs11209026) was considered a protective polymorphism (less frequently observed in patients than in controls) (Duerr et al., 2006; Glas et al., 2007). In contrast, our study showed the A allele of rs11209026 to be a risk variant.

Inflammation can be modulated by immune and non-immune systems, and immune responses are dependent on both innate and adaptive immunity. The mucosal immune response may be driven by an imbalance in cytokine signals that activates the STAT family factors (Musso et al., 2005). Induction of STAT3 transcriptional activity by IL23 and IL6 differentiates a subset of adaptive pro-inflammatory Th17 cells, effectors of immune response. These cells produce pro-inflammatory cytokines, such as IL17A, IL17F, IL19, IL20, IL22, IL24 (Chan et al., 2006; Iwakura \& Ishigame, 2006; Yen et al., 2006;
Zheng et al., 2007). While the IL23/IL23R pathway is thought to be involved in the etiology of various autoimmune-related disorders (Hue et al., 2006; Yen et al., 2006; Lubberts, 2007; Glas et al., 2007), the exposure of esophageal mucosa to low $\mathrm{pH}$ and bile acids in Barrett's esophagus leads to activation of STAT3 by IL6 (May et al., 2003; Yang et al., 2007). In turn, activated STAT3 may modulate antiapoptotic cellular reactions in Barrett's metaplasia. Thus, STAT3 is not only considered an essential regulator of immune-mediated inflammation (Yang et al., 2007), but also as an inflammatory-associated apoptosis resistance factor (Dvorak et al., 2007).

We recently applied microarray analysis to identify several genes differentially expressed between Barrett's metaplasia and squamous epithelium samples obtained from Barrett's esophagus patients (Ostrowski et al., 2007). Among them, a substantial fraction of genes were overrepresented in Barrett's metaplasia and could be assigned to functional categories related to the inflammatory response (i.e.: "immune response" and "inflammatory response"), as defined by Gene Ontology (Supplementary data and all MIAME complement microarray data are available at http://gastrolab.coi.waw. $\mathrm{pl} /$ barrett/). Among those genes, IL22R was over-expressed, while IL17RC, IL12A (p35), IL6R and IL6ST (interleukin 6 signal transducer; gp130, oncostatin $\mathrm{M}$ receptor) were under-expressed in Barrett's metaplasia. Interestingly, although the STAT3 and PIAS3 (STAT3 inhibitor) genes were downregulated in Barrett's metaplasia (Ostrowski et al., 2007), earlier immunohistochemical analyzes showed that nuclei of dysplastic Barrett's metaplasia exhibited activated STAT3 (Dvorak et al., 2007). Thus, the STAT3 signaling pathway may not only be shared by different forms of inflammation but also by different fundamental cellular processes.

Our statistical-based findings suggest that cytokine-activated STAT3 may be involved in the promotion of inflamed squamous epithelium into Barrett's metaplasia. However, the mechanisms underlying this transdifferentiation are as yet undetermined. 
It is also not clear if the observed risk variant of IL23R results in a functional alternation in cytokine signaling. As only one fourth of Barrett's esophagus patients carry the mutated IL23R risk gene variant, it is unlikely that mutations in this gene are related to the disease pathogenesis in a simple manner. Most likely, this and other susceptibility genes may act as Barrett's esophagus modifiers of the environmental response, and the hypothesized multifactor pathogenesis of Barrett's esophagus cannot be rejected. To fully elucidate the molecular consequences of the IL23R gene variations in Barrett's esophagus progression, our findings need to be verified by indepth functional assays, as well as case-control studies performed on substantially larger groups of patients.

\section{Acknowledgements}

This work was supported by the CMKP grant 501-1-1-09-17/05.

\section{REFERENCES}

Burton PR, Clayton DG, Cardon LR, Craddock N, Deloukas P, Duncanson A, Kwiatkowski DP, McCarthy MI, Ouwehand WH, Samani NJ, Todd JA, Donnelly P, Barrett JC, Davison D, Easton D, Evans DM, Leung HT, Marchini JL, Morris AP, Spencer CC, Tobin MD, Attwood AP, Boorman JP, Cant B, Everson U, Hussey JM, Jolley JD, Knight AS, Koch K, Meech E, Nutland $S$, Prowse CV, Stevens HE, Taylor NC, Walters GR, Walker NM, Watkins NA, Winzer T, Jones RW, McArdle WL, Ring SM, Strachan DP, Pembrey M, Breen G, St Clair D, Caesar S, Gordon-Smith K, Jones L, Fraser C, Green EK, Grozeva D, Hamshere ML, Holmans PA, Jones IR, Kirov G, Moskivina V, Nikolov I, O'Donovan MC, Owen MJ, Collier DA, Elkin A, Farmer A, Williamson R, McGuffin P, Young AH, Ferrier IN, Ball SG, Balmforth AJ, Barrett JH, Bishop TD, Iles MM, Maqbool A, Yuldasheva N, Hall AS, Braund PS, Dixon RJ, Mangino $\mathrm{M}$, Stevens S, Thompson JR, Bredin F, Tremelling $M$, Parkes $M$, Drummond $H$, Lees $C W$, Nimmo ER, Satsangi J, Fisher SA, Forbes A, Lewis CM, Onnie CM, Prescott NJ, Sanderson J, Matthew CG, Barbour J, Mohiuddin MK, Todhunter CE, Mansfield JC, Ahmad T, Cummings FR, Jewell DP, Webster J, Brown MJ, Lathrop MG, Connell J, Dominiczak A, Marcano CA, Burke B, Dobson R, Gungadoo J, Lee KL, Munroe PB, Newhouse SJ, Onipinla A, Wallace C, Xue M, Caulfield M, Farrall M, Barton A, Bruce IN, Donovan H, Eyre S, Gilbert PD, Hilder SL, Hinks AM, John SL, Potter C, Silman AJ, Symmons DP, Thomson W, Worthington J, Dunger DB, Widmer B, Frayling TM, Freathy RM, Lango H, Perry JR, Shields BM, Weedon MN, Hattersley AT, Hitman GA, Walker M, Elliott KS, Groves CJ, Lindgren CM, Rayner NW, Timpson NJ, Zeggini E, Newport M, Sirugo G, Lyons E, Vannberg F, Hill AV, Bradbury LA, Farrar C, Pointon JJ, Wordsworth P, Brown MA, Franklyn JA, Heward JM, Simmonds MJ, Gough SC, Seal S, Stratton MR, Rahman N, Ban M, Goris A, Sawcer SJ, Compston A, Conway D, Jallow M, Newport M, Sirugo G, Rockett KA, Bumpstead
SJ, Chaney A, Downes K, Ghori MJ, Gwilliam R, Hunt SE, Inouye M, Keniry A, King E, McGinnis R, Potter S, Ravindrarajah R, Whittaker P, Widden C, Withers D, Cardin NJ, Davison D, Ferreira T, Pereira-Gale J, Hallgrimsdo'ttir IB, Howie BN, Su Z, Teo YY, Vukcevic D, Bentley D, Brown MA, Compston A, Farrall M, Hall AS, Hattersley AT, Hill AV, Parkes M, Pembrey M, Stratton MR, Mitchell SL, Newby PR, Brand OJ, CarrSmith J, Pearce SH, McGinnis R, Keniry A, Deloukas P, Reveille JD, Zhou X, Sims AM, Dowling A, Taylor J, Doan T, Davis JC, Savage L, Ward MM, Learch TL, Weisman MH, Brown M (2007) Association scan of 14,500 nonsynonymous SNPs in four diseases identifies autoimmunity variants. Nat Genet 39: 1329-1337.

Cargill M, Schrodi SJ, Chang M, Garcia VE, Brandon R, Callis KP, Matsunami N, Ardlie KG, Civello D, Catanese JJ, Leong DU, Panko JM, McAllister LB, Hansen CB, Papenfuss J, Prescott SM, White TJ, Leppert MF, Krueger GG, Begovich AB (2007) A large-scale genetic association study confirms IL12B and leads to the identification of IL23R as psoriasis-risk genes. Am J Hum Genet 80: 273-290.

Chan JR, Blumenschein W, Murphy E, Diveu C, Wiekowski M, Abbondanzo S, Lucian L, Geissler R, Brodie S, Kimball AB, Gorman DM, Smith K, de Waal Malefyt R, Kastelein RA, McClanahan TK, Bowman EP (2006) IL-23 stimulates epidermal hyperplasia via TNF and IL-20R2-dependent mechanisms with implications for psoriasis pathogenesis. J Exp Med 203: 2577-2587.

di Martino E, Hardie LJ, Wild CP, Gong YY, Olliver JR, Gough MD, Bird NC (2007) The NAD(P)H:quinone oxidoreductase I C609T polymorphism modifies the risk of Barrett esophagus and esophageal adenocarcinoma. Genet Med 9: 341-347.

Duerr RH, Taylor KD, Brant SR, Rioux JD, Silverberg MS, Daly MJ, Steinhart AH, Abraham C, Regueiro M, Griffiths A, Dassopoulos T, Bitton A, Yang H, Targan S, Datta LW, Kistner EO, Schumm LP, Lee AT, Gregersen PK, Barmada MM, Rotter JI, Nicolae DL, Cho JH (2006) A genome-wide association study identifies IL23R as an inflammatory bowel disease gene. Science 314: 14611463.

Dvorak K, Chavarria M, Payne CM, Ramsey L, CrowleyWeber C, Dvorakova B, Dvorak B, Bernstein H, Holubec H, Sampliner RE, Bernstein C, Prasad A, Green SB, Garewal H (2007) Activation of the interleukin-6/ STAT3 antiapoptotic pathway in esophageal cells by bile acids and low $\mathrm{pH}$ : relevance to Barrett's esophagus. Clin Cancer Res 13: 5305-5313.

Glas J, Seiderer J, Wetzke M, Konrad A, Torok HP, Schmechel S, Tonenchi L, Grassl C, Dambacher J, Pfennig S, Maier K, Griga T, Klein W, Epplen JT, Schiemann U, Folwaczny C, Lohse P, Goke B, Ochsenkuhn T, MullerMyhsok B, Folwaczny M, Mussack T, Brand S (2007) rs1004819 is the main disease-associated IL23R variant in German Crohn's disease patients: combined analysis of IL23R, CARD15, and OCTN1/2 variants. PLoS ONE 2: e819.

Gough MD, Ackroyd R, Majeed AW, Bird NC (2005) Prediction of malignant potential in reflux disease: are cytokine polymorphisms important? Am J Gastroenterol 100: 1012-1018.

Hue S, Ahern P, Buonocore S, Kullberg MC, Cua DJ, McKenzie BS, Powrie F, Maloy KJ (2006) Interleukin-23 drives innate and $\mathrm{T}$ cell-mediated intestinal inflammation. J Exp Med 203: 2473-2483.

Iwakura Y, Ishigame H (2006) The IL-23/IL-17 axis in inflammation. J Clin Invest 116: 1218-1222. 
Kala Z, Dolina J, Marek F, Izakovicova Holla L (2007) Polymorphisms of glutathione S-transferase M1, T1 and P1 in patients with reflux esophagitis and Barrett's esophagus. J Hum Genet 52: 527-534.

Koj A, Jura J (2003) Complex analysis of genes involved in the inflammatory response: interleukin-1-induced differential transcriptome of cultured human hepatoma HepG2 cells. Acta Biochim Polon 50: 573-582.

Krishnadath KK (2007) Novel findings in the pathogenesis of esophageal columnar metaplasia or Barrett's esophagus. Curr Opin Gastroenterol 23: 440-445.

Lubberts E (2008) IL-17/Th17 targeting: On the road to prevent chronic destructive arthritis? Cytokine 41: 84-91.

May P, Schniertshauer U, Gerhartz C, Horn F, Heinrich PC (2003) Signal transducer and activator of transcription STAT3 plays a major role in gp130-mediated acute phase protein gene activation. Acta Biochim Polon 50: 595-601.

Murphy SJ, Hughes AE, Patterson CC, Anderson LA, Watson RG, Johnston BT, Comber H, McGuigan J, Reynolds JV, Murray LJ (2007) A population-based association study of SNPs of GSTP1, MnSOD, GPX2 and Barrett's esophagus and esophageal adenocarcinoma. Carcinogenesis 28: 1323-1328.

Musso A, Dentelli P, Carlino A, Chiusa L, Repici A, Sturm A, Fiocchi C, Rizzetto M, Pegoraro L, Sategna-Guidetti C, Brizzi MF (2005) Signal transducers and activators of transcription 3 signaling pathway: an essential mediator of inflammatory bowel disease and other forms of intestinal inflammation. Inflamm Bowel Dis 11: 91-98.

Ostrowski J, Rubel T, Wyrwicz LS, Mikula M, Bielasik A, Butruk E, Regula J (2006) Three clinical variants of gastroesophageal reflux disease form two distinct gene expression signatures. J Mol Med 84: 872-882.

Ostrowski J, Mikula M, Karczmarski J, Rubel T, Wyrwicz LS, Bragoszewski P, Gaj P, Dadlez M, Butruk E, Regula J (2007) Molecular defense mechanisms of Barrett's metaplasia estimated by an integrative genomics. $\mathrm{J} \mathrm{Mol}$ Med 85: 733-743.

Yang XO, Panopoulos AD, Nurieva R, Chang SH, Wang D, Watowich SS, Dong C (2007) STAT3 regulates cytokine-mediated generation of inflammatory helper $\mathrm{T}$ cells. J Biol Chem 282: 9358-9363.

Yen D, Cheung J, Scheerens H, Poulet F, McClanahan T, McKenzie B, Kleinschek MA, Owyang A, Mattson J, Blumenschein W, Murphy E, Sathe M, Cua DJ, Kastelein RA, Rennick D (2006) IL-23 is essential for $\mathrm{T}$ cell-mediated colitis and promotes inflammation via IL-17 and IL-6. J Clin Invest 116: 1310-1316.

Zheng Y, Danilenko DM, Valdez P, Kasman I, EasthamAnderson J, Wu J, Ouyang W (2007) Interleukin-22, a $\mathrm{T}(\mathrm{H}) 17$ cytokine, mediates IL-23-induced dermal inflammation and acanthosis. Nature 445: 648-651. 